\title{
What is the teacher's challenge on the developing of learning media to increase critical thinking ability and the character?
}

\author{
Muhammad Sulthon *, Pratiwi Pujiastuti, Heri Retnawati \\ Universitas Negeri Yogyakarta. Jalan Colombo No. 1, Yogyakarya 55281, Indonesia \\ * Corresponding Author. E-mail: msulthon5@gmail.com
}

Received: 4 October 2020; Revised: 27 November 2020; Accepted: 15 December 2020

\begin{abstract}
The development of technology makes learning media have an essential function for the learning process conducted by the teacher to students. However, in reality, there are still many teachers who have not yet implemented the development of learning media to support the learning program. The purpose of this study is to describe the challenges and problems that occur in the development of learning media to improve critical thinking skills and character. This study examines how the challenges of teachers in developing learning media to improve students' critical thinking skills and character. The method was in the form of qualitative data (phenomenology). Data were collected by conducting interviews and observations on nine teachers from 3 public elementary schools in Sleman Regency, Yogyakarta, Indonesia. Based on research, it conducted that students' critical thinking skills and character will increase if the teacher can solve or face challenges in developing existing learning media.
\end{abstract}

Keywords: Learning media, critical thinking, character, elementary school

How to Cite: Sulthon, M., Pujiastuti, P., \& Retnawati, H. (2021). What is the teacher's challenge on the developing of learning media to increase critical thinking ability and the character?. Jurnal Prima Edukasia, 9(1), 55-64. doi:https://doi.org/10.21831/jpe.v9i1.34876

\section{Introduction}

Education recently has quite complex challenges to be faced. The existing challenges could come from both teachers and students, so it makes teachers must be creative and innovative and always develop accordingly. Education is a guide to live and navigate life within times. Therefore, teachers must be able to process learning media accordingly. The design of learning media must be accustomed to a quality product so that it has a good impact on students. Amir and Kusuma W. (2018) revealed that a quality learning product must meet valid, practical, and productive aspects. Therefore, the design of a learning media must pay attention to many aspects in order to approach product perfection.

Learning media are the tools used to help the learning process that the teacher goes through. Learning media makes it easy for teachers to deliver material to the students. Essentially, it is a learning media to facilitate the learning process. For example, the material that is difficult to explain through a speech can be explained through a learning media or device. In the classroom, learning media becomes essential and has a positive impact both in the course of learning and education. The knowledge and ability of technology to develop learning media in the university are taught in different subjects (Mcgrath et al., 2011). Furthermore, the learning media have been taught in the college for the prospective lecture. In practice, the implementation of learning media is still minimal.

Mostly, the learning process still does not use learning media, so what happens is an only teachercentered learning process. To suppress the teacher-centered learning process, qualified learning media is needed. Planning in the preparation of learning media must also be carried out. A teacher should have skills in design on the learning media to be designed. Amir and Kusuma W (2018) said that the preparation of learning media must be based on Define, Design, and Develop. In this process, the teacher often does not understand in the preparation following the rules of developing a learning media. Not to forget, the teacher must be able to arrange learning media that are per the conditions and needs of students before starting the learning process (Lutfi, 2019). Therefore some obstacles occurred so that the process will stop and cause teachers to be reluctant to design the development process.

The teachers know that the development of education must follow the development of technology. However, in reality, the teacher does not have a strong desire to compile a learning media. Indeed they 
Jurnal Prima Edukasia, 9 (1), 2021 - 56

Muhammad Sulthon, Pratiwi Pujiastuti, Heri Retnawati

are aware that the development of learning media is needed. Nevertheless, the lack of knowledge and proper mentoring in the school and teacher environment makes teachers reluctant to developing a learning media. Eggen and Kaucak (2012) stated that teachers must have professional knowledge and a vast range of teaching strategies. Even in terms of time, the teacher feels very burdened when required to develop it. Either non-civil servant teachers or honorary teachers in public elementary schools has minimal salaries. They prefer to look for additional income rather than just putting together a learning media that is compatible with learning. As a result, teachers prefer to use available textbooks that come from the government and only use the worksheets.

Furthermore, in terms of facilities and infrastructure at school, it still does not support the achievement of active learning. It often found, especially in state primary schools, that some of the classes are equipped with electronic equipment to support learning. For example, there is still no electronic class equipment, namely projectors and sound, to help the learning process, Even though electronic learning media are needed in this modern era. Chaidar (2014) said that the use of information and communication technology in learning is carried out in order to improve effectiveness in the implementation of the learning process, which is ultimately expected to improve student learning outcomes and the individual quality of students in terms of using technology more precisely and beneficially. It makes the learning process in the classroom only teacher-centered learning.

Based on observations in January 2019 conducted at the Perumnas Condongcatur Elementary School, Depok sub-district, Sleman district, Yogyakarta province, Indonesia, the process of using different learning media has not been conducted by teachers. Then based on interviews with the teacher, grade IV students explained that the learning media that are arranged independently by the teacher are indeed still rarely done. It has an impact on the lack of independence of students in learning. The learning media has the function as one of the independent teaching materials in the sense of minimizing the role of the teacher in the learning process. The facts that occur in the science learning process are the use of lecture methods and are still limited to presenting routine questions.

The students looked unenthusiastic when implementing learning because of only doing work on problems and memorization, which is characterized by a lack of student curiosity. Moreover, when the teacher reflects on the students and asks if there are any questions, the students just fall silent. It describes the ability of students still limited to do routine questions that do not require higher-order thinking skills. Increased critical thinking skills and interpersonal intelligence can occur through the use of problembased learning models (Amrullah \& Suwarjo, 2018). Students are not accustomed to problem-solving learning, which results in weak development of critical thinking processes. Generally, students who have critical thinking will use basic principles and concepts to answer "how" and "why" questions (Syarifuddin, 2018), but this has not been seen in the classroom. As a result, students' ability to think critically, that is, the ability to evaluate their own beliefs and opinions, is not well developed.

Character education also needs to be embedded in every lesson. No exception to the learning media that will be arranged must be guided by character education. Gunawan (2012) stated that character education is the efforts that are designed and carried out systematically to instill the values of student behavior related to God Almighty, individual, fellow human beings, the environment, and nationality that are manifested in the mind, the attitude of feelings, words, and actions based on religious norms, law, karma, culture, and customs. Diani (2015) stated that character education could be believed to be an essential aspect of education, especially in efforts to increase Human Resources. The purpose of character education reflects the importance of character education to support the success of students, both in academic and social life (Zurqoni et al., 2018).

Rahayu and Firmansyah (2019) revealed that the existence of community service in the form of assistance for elementary school teachers could improve the quality of teachers and the learning process in the Cipendeuy District of West Bandung Regency. The need for mentoring owned by the teacher in the preparation of learning media. According to Diani's research (2015), after observing, it turns out that the learning media used by teachers in learning do not support the achievement of these objectives, for example, the syllabus (Diani, 2015). The syllabus used by teachers is not based on character education. The Learning Implementation Plan that the teacher uses is still incomplete. There are still many teachers who only focus on using worksheets and working on problems. It was concluded that the learning media used in learning could not yet support the creation of better student activities, competencies, and characters. the urgency of using media in the learning process for elementary school teachers based on 
Jurnal Prima Edukasia, 9 (1), 2021 - 57

Muhammad Sulthon, Pratiwi Pujiastuti, Heri Retnawati

40 teachers as respondents in the unimportant and less important category $00.00 \%$, seven teachers or $17.5 \%$ said it was necessary, and 33 teachers or $82.5 \%$ said very important (Rafiuddin et al., 2017).

Learning media should have a plan. Moon et al. (2002) stated "the effective teacher is very systematic in preparation for, and execution, of each lesson." Teachers, in this case, must be more active in developing their competencies. Not only in themselves but also in colleagues are needed in strategies to face the challenges that occur in the preparation of learning media. Based on the designs that have been developed, compiled learning media are needed. The process of preparing learning media consists of three main stages. First, determine learning strategies and appropriate learning media. At this stage, it is necessary to pay attention to the various characteristics of the competencies to be learned, the characteristics of students, and the characteristics of the context and situations in which learning media will be used. Second, produce or realize physical learning media. Components of the contents of the learning kit include: learning objectives, required learners prerequisites, substance or learning material, forms of learning activities, and supporting components. Third, develop assessment tools. In this case, it should be noted that all aspects of competence (knowledge, skills, and related attitudes) can be assessed based on specific predetermined criteria. The mentoring process must also be carried out in the preparation of a learning media. Therefore, the teacher community is needed in the strategy in designing this learning media.

\section{Method}

This research was qualitative research with a phenomenological approach. This research described how the challenges faced by teachers in the preparation of learning media. This research study used a qualitative approach using the phenomenological method. The use of this method to describe the challenges faced by teachers in developing learning media to support the learning process.

Conducted by interview and participatory observation, the subjects were teachers and students from 3 elementary schools. Public primary schools were selected as the same criteria, namely SD Negeri Perumnas Condongcatur, SD Negeri Condongcatur, SD Negeri Karangasem, which located in the Depok sub-district, Sleman regency, provision of Yogyakarta, Indonesia. Interviews were conducted, each with 3 class teachers in each elementary school. The steps taken are the analysis, including interviews with teachers and students.

Data were collected by interviews and observations on teacher participation in school. An initial interview was conducted to find out the teacher's understanding of the learning media. Next, participant observation was conducted to observe the implementation of learning how the process of using the learning media used by the teacher. Data collection was also carried out with a second interview about the obstacles, constraints, and challenges faced by the teacher regarding developing learning media. Then, students are observed and interviewed about the learning that has been done, whether it meets and matches the students' critical thinking skills and character. So, challenging data will be obtained that occur faced by the teacher in the learning media process.

Data from interviews and observations are then reduced. The reduction results are presented in a tabular table in the form of sub-themes, which later become a theme. Data analysis was obtained based on the relationship between themes formed to gain understanding. The relationship between themes contained in the inference data is used to gain an understanding of the challenges of teachers in developing learning media. In this study, all data were coded so that participants' confidentiality was guaranteed. Besides, during the interview and observation process, the researcher told the participants that this data collection did not affect the participant's teacher's career.

\section{Results and Discussion}

\section{Result}

The interview and observation data obtained by means grouped according to theme into the primary material to be reduced and sought subthemes. After that, it is connected between sub-themes to get a conclusion.

\section{Teacher Conditions in Understanding the Learning Media}

Learning media are the tools that are used to help the learning process that the teacher goes through. Learning media in the learning process also makes it easier for teachers to deliver material to 
Jurnal Prima Edukasia, 9 (1), 2021 - 58

Muhammad Sulthon, Pratiwi Pujiastuti, Heri Retnawati

students. The nature of learning media are tools in the learning process and can certainly make it easier. The teacher's awareness of the importance of the learning media is already owned. The teachers are aware that learning media are indeed needed in the learning process. In its application, the learning media is indeed quite helpful. The existence of learning media also provides a new atmosphere faced by students. As seen in Table 1, the study result of teacher conditions in understanding the learning media is presented.

Table 1. Teacher Conditions in Understanding the Learning Media

\begin{tabular}{clll}
\hline No. & \multicolumn{1}{c}{ Sub-theme } & The relationship of sub-themes & \multicolumn{1}{c}{ Conclusions } \\
\hline 1. & $\begin{array}{l}\text { The teacher knows the learning } \\
\text { media in elementary school }\end{array}$ & $\begin{array}{l}\text { Teacher knowledge about } \\
\text { learning media }\end{array}$ & $\begin{array}{l}\text { Teachers need a variety of } \\
\text { learning media in the learning } \\
\text { process }\end{array}$ \\
2. $\begin{array}{l}\text { The teacher knows how important } \\
\text { learning media are. }\end{array}$ & & \\
3. $\begin{array}{l}\text { The teacher is happy with learning if } \\
\text { he has many learning media. }\end{array}$ & & \\
\hline
\end{tabular}

Based on Table 1, the teacher understanding on learning media was quite good. It resulted that teachers knew the learning media, knew how important learning media are, and were happy with many variation of learning media. Therefore, it concluded that teachers need a variety of learning media in the learning process. Besides helping to provide variations in the learning process, learning media have a positive impact on the mastery of the material faced by students. Material limitations will be helped by a variety of learning media. Learning media also must, of course, consider several aspects that must be met in the learning process. Both following the existing curriculum and ease of use. It all makes learning media better and can help in the learning process. The teacher is aware of it all that the learning process will be helped by a variety of learning media.

\section{The Challenges Faced by Teachers in the Preparation of Learning Media}

Indeed, in the process of preparing learning media requires very much energy. Teachers must set aside time, effort, and part of their income to develop learning media. Unfortunately, there are still many teachers who lack the awareness to compile and sacrifice this time to develop learning media. Lack of attention from the government is also a separate obstacle in the process. Both in terms of facilities, funds spent and mentoring in the preparation process. The Challenges in the learning media preparation is seen in Table 2.

Table 2. The Challenges Faced by Teachers in the Preparation of Learning Media

\begin{tabular}{clll}
\hline No. & \multicolumn{1}{c}{ Sub-theme } & The relationship of sub-themes & \multicolumn{1}{c}{ Conclusions } \\
\hline 1. & $\begin{array}{l}\text { The absence of the process of mentoring and } \\
\text { assistance in preparing the right learning } \\
\text { media. }\end{array}$ & $\begin{array}{l}\text { Facilities obtained by teachers } \\
\text { are limited }\end{array}$ & $\begin{array}{l}\text { Lack of facilities, } \\
\text { attention, and } \\
\text { awareness of teachers } \\
\text { to develop learning } \\
\text { 2. }\end{array}$ \\
Limited funds owned by the teacher. & $\begin{array}{l}\text { There is no time in the preparation of learning } \\
\text { media. }\end{array}$ & $\begin{array}{l}\text { Lack of attention given to } \\
\text { teachers }\end{array}$ & media \\
4. $\begin{array}{l}\text { Salaries given to teachers, especially honorary } \\
\text { teachers, are insufficient, so teachers are } \\
\text { reluctant to develop learning media. }\end{array}$ & & \\
\hline
\end{tabular}

Based on Table 2, the challenges on learning media preparation were lack of provided facility and less concern on the teacher. It was indicated by the absence of mentoring and monitoring on learning media preparation, limited fund by teacher, no time on learning media preparation, and insufficient salary of the teacher especially honorary teacher. The insufficient salary makes teacher reluctant to prepare learning media, thus, they preferred find another secondary income such as private lecture. Especially for teachers with honorary status, cost constraints are the main obstacle in the preparation process. Without realizing it, they are reluctant to compile learning media due to time and cost constraints. Honorary teachers prefer to look for other income rather than spend their time to develop learning media. It is common knowledge that the salary of honorary teachers in public elementary schools in the Sleman Regency, Yogyakarta province, Indonesia, ranges from 500,000 to 600,000 rupiahs every month. Indeed, the nominal is not sufficient for their daily lives, especially if they are required to compile learning media that cost a lot. 
Jurnal Prima Edukasia, 9 (1), 2021 - 59

Muhammad Sulthon, Pratiwi Pujiastuti, Heri Retnawati

\section{The Role of Government}

The government, especially the Sleman District Education Office, does not remain silent. The local Education Office has encouraged so that teachers are moved to develop learning media independently. However, in the application process, the socialization carried out was not very useful. From the interviews conducted with the teachers, they felt confused when asked about the preparation of the learning program in the form of modules. Based on the answers from the teachers, many of them were not aware of the existence of a learning program preparation program in the form of modules implemented by the government. It indicates that the socialization conducted by the government is lacking. The problem also occurs, namely the frequent change in leadership at the government, so it has an impact of a policy change. The role of government on learning media preparation is presented in Table 3.

Table 3. The Role of Government

\begin{tabular}{|c|c|c|c|}
\hline No. & Sub-theme & The relationship of sub-themes & Conclusions \\
\hline 1. & $\begin{array}{l}\text { The government provides } \\
\text { competition for the preparation } \\
\text { of learning media. }\end{array}$ & $\begin{array}{l}\text { The role of government in } \\
\text { encouraging the development of } \\
\text { learning media }\end{array}$ & $\begin{array}{l}\text { The government still pays little } \\
\text { attention to the effectiveness in } \\
\text { implementing a policy }\end{array}$ \\
\hline 2. & $\begin{array}{l}\text { The socialization of the learning } \\
\text { media preparation competition is } \\
\text { lacking. }\end{array}$ & & \\
\hline & $\begin{array}{l}\text { The teacher is not aware of the } \\
\text { competition. }\end{array}$ & & \\
\hline
\end{tabular}

Based on Table 3, the role of government is needed in the preparation of learning tools for teachers. This is indicated by the policy carried out by the local office, namely the government providing a competition for the preparation of learning tools. However, the teacher, when interviewed, stated that the socialization of the competition for the preparation of learning media was lacking, so that the teachers were less aware of the policy. The role and synergy of the government in encouraging the preparation of learning tools in the form of a pro-teacher policy are needed. In fact, government policies are still ineffective in their implementation. Therefore, the role of government must pay more attention to effectiveness and efficiency in accordance with the needs of teachers.

\section{Learning Media at School}

Facilities owned by public elementary schools are also somewhat lacking. For example, projectors owned by schools are not complete in all classes. Even though the projector itself is quite helpful in the learning process on the material, of course. For textbooks, teachers use textbooks and student worksheets provided by the central government, namely the Ministry of Education and Culture of the Republic of Indonesia. In the teaching materials, textbooks are guided by character education. The Government of the Republic of Indonesia has the primary goal of inculcating character education in students so that the textbooks have been adjusted accordingly. Table 4 shows the results of research in the form of learning media in the school.

Table 4. Learning Media at School

\begin{tabular}{clll}
\hline No. & \multicolumn{1}{c}{ Sub-theme } & \multicolumn{1}{c}{ The relationship of sub-themes } & \multicolumn{1}{c}{ Conclusions } \\
\hline 1. & $\begin{array}{l}\text { Books provided by the government have } \\
\text { supported character education. }\end{array}$ & $\begin{array}{l}\text { The condition of learning media } \\
\text { in schools }\end{array}$ & $\begin{array}{l}\text { The lack of learning media } \\
\text { provided by schools }\end{array}$ \\
2. $\begin{array}{l}\text { Teachers more often use textbooks or } \\
\text { student worksheets from the }\end{array}$ & & \\
government. & $\begin{array}{l}\text { Facilities owned by the school are still } \\
\text { lacking. }\end{array}$ & $\begin{array}{l}\text { Limitations of learning media, } \\
\text { materials and teaching materials }\end{array}$ \\
4. $\begin{array}{l}\text { The coverage of material in the book is } \\
\text { limited. }\end{array}$ & \\
5ooks are still lacking in students' & & \\
\hline
\end{tabular}


Jurnal Prima Edukasia, 9 (1), 2021 - 60

Muhammad Sulthon, Pratiwi Pujiastuti, Heri Retnawati

As described on Table 4 regarding on the availability of learning media in the school, teachers tend to use textbook or workbook from the government, lack variation of school's learning media were, material coverage in books were limited which only provided by textbook and workbook, the books were lack in stimulating critical thinking but books were provided by the government have supported character education for students. Obviously, the variety of learning resources and learning tools provided by schools is quite visible based on the results of interviews and observations at school. In interviews with teachers, character education in learning is always applied. However, critical thinking skills are still lacking. The material in the package book is considered too shallow in terms of the broad nature of material delivery. Even though students are given detailed questions in the exam. Therefore the critical thinking skills possessed by students are less honed in the learning process. Plus, the lack of variety of learning media in the classroom.

\section{Discussions}

\section{Teacher Conditions in Understanding the Learning Media}

Learning media are tools that are used to help the learning process that the teacher goes through. Essentially, the learning media is a tool in the learning process so that it can facilitate, of course. Learning using learning media produces quality learning because the ideas that teachers have can be expressed systematically and structured in learning (Muzanni \& Muhyadi, 2016). In interviews conducted with teachers, that awareness of the importance of learning media in supporting the sustainability of learning activities in the classroom is already owned. The existence of learning media also provides a new atmosphere faced by students. Following research from Suardana and Retug (2017), teachers have an awareness of the ability to design learning media needed. Besides helping to provide variations in the learning process, learning media have a positive impact on the mastery of the material faced by students. Burden \& Byrd (Santrock, 2011) states that "planning is the critical aspect of being a competence teacher." Material limitations will be helped by a variety of learning media. Learning media also must, of course, consider several aspects that must be met in the learning process. Both following the existing curriculum and ease of use. Effective teachers are teachers who have systematic preparation and implementation of learning (Moon et al., 2002).

Therefore, learning media are needed to support the effectiveness of the learning process carried out by the teacher. However, not only learning tools are needed but also variations in learning tools are also needed in the teaching process of teachers. In teacher-centered learning, students are often passive in learning, lack of variation in learning and bored during the learning process (Fadhli, 2015). Inside the interactive media in learning, there are variations in learning and teaching activities (Rachmadtullah et al., 2018). With the variety of learning tools, students are expectedly not felt bored with the learning process. From research conducted by Ratminingsih (2016) in five elementary schools, the role of media was very significant in improving student learning outcomes. By using variations media, in addition the learning was more interesting and joyful, it would make easy the students comprehending all of the material content taught (Mudiono, et al., 2016).

\section{The Challenges Faced by Teachers in the Preparation of Learning Media}

Teachers must set aside time, effort, and part of their income to develop learning media. Unfortunately, there are still many teachers who lack the awareness to compile and sacrifice all these aspects to compile the learning media. It is confirmed by Purwati and Kurniawan (2018) research that salary had a significant effect on the performance of teachers and employees at Esa Sejahtera School Pekanbaru. The biggest obstacle owned by honorary or novice teachers is their low salaries. From interviews conducted, they prefer to look for other income rather than spend their time to compile learning media that the preparation process takes much time. In Chand's (2015) research, he faced similar problems; namely, teachers were often under-paid in terms of honorarium, low salary, no job security, and long working hours. In the end, time to arrange learning media is reduced for other jobs. Beginner teachers prefer to use their time to find additional income. In line with Retnawati research time is limited, so that teachers have difficulties related to the development of learning media (Retnawati, 2016).

The mentoring process is also needed in learning media preparation, but there is still lack of support from the school and government. The mentoring process certainly requires the role of the learning media expert. This is confirmed by Anugraheni (2017) research that problems with teacher planning 
Jurnal Prima Edukasia, 9 (1), 2021 - 61

Muhammad Sulthon, Pratiwi Pujiastuti, Heri Retnawati

in using learning methods and media still occur. It requires monitoring and teacher guidance in the process of learning media preparation. Moreover, in the field of technology, experts are needed. In the research of Sinsuw and Sambul (2017), information technology-based learning media development training really helps teachers in mastering the use of technology and teachers become more communicative and creative so that teaching materials arouse students' enthusiasm for learning. However, all of these components have not been fulfilled in terms of the obstacles faced by the teacher.

\section{The Role of Government}

Lack of attention from the government is also a constraint, both in terms of facilities, funds released, and other supporting facilities. The teachers in the interview also have obstacles in terms of mentoring in the preparation of learning media. Therefore here, the companion process must always be given to the teacher in the framework of a teacher's self-development. In line with the results of research Asmara et al. (2016) that mentoring or mentoring activities can improve teacher understanding of designing learning media activities. The results of Shanks research (2017) that mentoring beginner teachers also need to be done in facilitating professional teachers. Putri and Imaniyati (2017) stated that professionalism development of teacher improves with (1) Keeping up of science and technology development that supports their profession through various scientific activities, (2) Developing various learning media, (3) Writing scientific paper, (4) Making props/media, (5) Attending certified training, (6) Participating in curriculum development activities. With the presence of mentoring from government, it obviously affects teacher professionalism which tends to be positive ways for the students.

The local Education Office has encouraged so that teachers are moved to prepare the learning media independently. Nevertheless, in the process of applying it, the socialization that was carried out was not adequate. Many teachers were not aware of the competition. Programs that are designed can contribute positively to improving teacher performance (Gunawan, 2015). The frequent change of leadership in the central government also presents problems and impacts on the policies taken. Therefore, it should, the local government must make a useful contribution to policy. Not only creating it but must also monitor how the program runs well.

\section{Learning Media at School}

Facilities owned by schools are also somewhat lacking. For textbooks, teachers use textbooks and student worksheets provided by the central government, namely the Ministry of Education and Culture of the Republic of Indonesia. However, the provision of teaching materials in the form of textbooks has been guided by character education. In Ardales et al. (2016) there are often problems in teaching, namely the lack of teaching materials and difficulty in preparing for learning. It was observed that students usually fail in examinations owing to improper teaching methods and lack of essential teaching aids for instructional delivery (Olayinka, 2016). The government hopes that teachers are expected to explore activities in the child's environment. Character education is one of the outcomes of the curriculum that must be implemented in education in Indonesia. However, in reality, the teachers found it challenging to apply. Therefore, here it is necessary to develop an effective learning media to encourage learning to improve student character education. The results of research Susanto and Retnawati (2016) explained that the development of learning media could increase the activeness and attitudes of students towards learning, in this case, higher-order thinking skills.

The teachers in this study were also still lacking in implementing problem-based learning. Students who are not familiar with problem-solving learning will have an impact on the weak development of the critical thinking process. Therefore critical thinking skills possessed by students must always be done. From the results of a survey of teachers, learning media with critical thinking discovery models are needed, as alternative learning in the classroom (Khomsiatun \& Retnawati, 2015). Plus, the lack of a variety of learning media in the classroom makes students lack critical thinking skills. By the results of Jailani and Retnawati's research (2016) that the use of problem-based learning media is also capable of improving student character. So from this, it can be concluded here that there is a connection between problem-based learning that will impinge on the inculcation of the character of the student

\section{Conclusions}

Based on the results of this study, the real challenges of teachers in the preparation of learning media are very complex. Starting from the lack of learning media available in schools, the lack of the 
Jurnal Prima Edukasia, 9 (1), 2021 - 62

Muhammad Sulthon, Pratiwi Pujiastuti, Heri Retnawati

role of the government in supporting the achievement of a good education, and the challenges faced by teachers in the preparation of learning media. Therefore, the collaboration between the government and teachers is needed. Teachers and the government must work together to advance education. The creation of the nation's golden generation even started from early education. Therefore the role of government in implementing effective policies must be carried out. Not only creating policies without monitoring policies that are already running.

Not also forgetting the role of the teacher in the learning process that is providing variations in learning is vital. Indeed, what must be paid more attention to advancing the Education process is the welfare of the teachers. With welfare, the teacher's sense of responsibility will be more awakened. Because the process of development of the times is swift, If the teacher does not always learn and upgrade his knowledge, gradually, the teacher will be left behind with technology, and it will have an impact on students. For teachers, they must be more enthusiastic about developing their knowledge.

\section{References}

Amir, M. F., \& Kusuma W, M. D. (2018). Pengembangan perangkat pembelajaran berbasis masalah kontekstual untuk meningkatkan kemampuan metakognisi siswa sekolah dasar. Journal of Medives : Journal of Mathematics Education IKIP Veteran Semarang, 2(1), 117. https://doi.org/10.31331/medives.v2i1.538

Amrullah, K., \& Suwarjo, S. (2018). The effectiveness of the cooperative problem-based learning in improving the elementary school students' critical thinking skills and interpersonal intelligence. Jurnal Prima Edukasia, 6(1), 66. https://doi.org/10.21831/jpe.v6i1.11253

Anugraheni, I. (2017). Analisa faktor-faktor yang mempengaruhi proses belajar guru-guru sekolah dasar. Kelola: Jurnal Manajemen Pendidikan, 4(2), 205. https://doi.org/10.24246/j.jk.2017.v4.i2.p205-212

Ardales Jr., G. Y., Espaldon, M. V. O., Lasco, R. D., Quimbo, M. A. T., \& Zamora, O. B. (2016). Impacts of floods on public schools in the municipalities of Los Baños and Bay, Laguna, Philippines. Journal of Nature Studies, 15(1), 19-40.

Asmara, J., Massawet, E. T., \& Rambitan, V. M. . (2016). Analisis permasalahan guru terkait pengembangan perangkat pembelajaran berbasis model think talk write (TTW) dan permasalahan siswa terkait keterampilan bertanya siswa dalam pembelajaran IPA biologi. Jurnal Pendidikan: Teori, Penelitian, Dan Pengembangan, 1(10), 2059-2065. https://doi.org/10.17977/jp.v1i10.7952

Chaidar, H. (2014). Pemanfaatan teknologi informasi dan komunikasi dalam pembelajaran di SMA Muhammadiyah Tarakan. Jurnal Kebijakan Dan Pengembangan Pendidikan, 2(2), 184-192. https://doi.org/10.22219/jkpp.v2i2.1917

Chand, D. (2015). Major problems and issues of teacher education. International Journal of Applied Research, 1(4), 350-353.

Diani, R. (2015). Pengembangan perangkat pembelajaran fisika berbasis pendidikan karakter dengan model problem based instruction. Jurnal Ilmiah Pendidikan Fisika Al-Biruni, 4(2), 243. https://doi.org/10.24042/jpifalbiruni.v4i2.96

Eggen P., \& Kaucak, D. (2012). Strategi dan model pembelajaran (mengajarkan kontent dan ketrampilan berpikir). (S. Wahono (ed.)). Jakarta: PT Indeks.

Fadhli, M. (2015). Pengembangan media pembelajaran berbasis video kelas IV sekolah dasar. Jurnal Dimensi Pendidikan Dan Pembelajaran, 3(1), 24-29. https://doi.org/10.24269/dpp.v3i1.157

Gunawan, H. (2012). Pendidikan karakter: Konsep dan implementasi. Alfabeta.

Gunawan, I. (2015). Strategi meningkatkan kinerja guru: Apa program yang ditawarkan oleh kepala sekolah. Prosiding Seminar Nasional Pengembangan Karir Tenaga Pendidik Berbasis Karya Ilmiah, 305-312. http://ap.fip.um.ac.id/wp-content/uploads/2015/04/36_Imam-Gunawan-AP.pdf

Jailani, J., \& Retnawati, H. (2016). Keefektifan pemanfaatan perangkat pembelajaran berbasis masalah untuk meningkatkan HOTS dan karakter siswa. Jurnal Pendidikan Dan Pembelajaran, 23(2), 111-123. http://journal.um.ac.id/index.php/pendidikan-dan-pembelajaran/article/view/10162 
Jurnal Prima Edukasia, 9 (1), 2021 - 63

Muhammad Sulthon, Pratiwi Pujiastuti, Heri Retnawati

Khomsiatun, S., \& Retnawati, H. (2015). Pengembangan perangkat pembelajaran dengan penemuan terbimbing untuk meningkatkan kemampuan pemecahan masalah. Jurnal Riset Pendidikan Matematika, 2(1), 92. https://doi.org/10.21831/jrpm.v2i1.7153

Lutfi, A. (2019). Pengembangan perangkat pembelajaran menggunakan problem solving dalam problem posing berbasis pendekatan saintifik. Jurnal Riset Pendidikan Matematika, 6(1), 27 38. https://doi.org/10.21831/jrpm.v6i1.10231

Mcgrath, J., Karabas, G., Willis, J., John, S., College, F., \& Rochelle, N. (2011). From TPACK concept to TPACK practice: An analysis of the suitability and usefulness of the concept as a guide in the real world of teacher development. International Journal of Technology in Teaching and Learning, 7(1), 1-23.

Moon, B., Mayes, A. S., \& Hutchinson, S. (2002). Teaching, learning and the curriculum in secondary school. Routledge Falmer.

Muzanni, A., \& Muhyadi, M. (2016). Pengembangan perangkat pembelajaran problem solving mata pelajaran IPA terhadap hasil belajar kognitif siswa SD. Jurnal Prima Edukasia, 4(1), 1. https://doi.org/10.21831/jpe.v4i1.7746

Olayinka, A.-R. B. (2016). Effects of instructional materials on secondary schools students' academic achievement in social studies in Ekiti State, Nigeria. World Journal of Education, 6(1), 32-39. https://doi.org/10.5430/wje.v6n1p32

Purwati, A. A., \& Kurniawan, J. (2018). Analisis pengaruh gaji, kedisiplinan dan pembagian kerja terhadap kinerja guru dan karyawan di Sekolah Esa Sejahtera Pekanbaru. Cano Economos, 7(1), 16-24. https://e-journal.upp.ac.id/index.php/Cano/article/view/1488

Putri, A. D. K., \& Imaniyati, N. (2017). Professional development of teachers in improving the performance of teacher. Jurnal Pendidikan Manajemen Perkantoran, 2(2), 202-211.

Rachmadtullah, R., Nadiroh, N., Sumantri, M. S., \& S, Z. M. (2018). Development of interactive learning media on civic education subjects in elementary school. Proceedings of the Annual Civic Education Conference (ACEC 2018), 251(Acec), 293-296. https://doi.org/10.2991/acec18.2018.67

Rafiuddin, R., Basri, M., \& Azis, M. (2017). Urgensi penggunaan media dalam proses pembelajaran bagi guru sekolah dasar wilayah II Kecamatan Sanrobone Kabupaten Takalar Provinsi Sulawesi Selatan. Seminar Nasional Teknologi Pembelajaran Dan Pendidikan Dasar 2017, 2(3), 147157. http://pasca.um.ac.id/conferences/index.php/sntepnpdas/article/view/856

Rahayu, G. D. S., \& Firmansyah, D. (2019). Pengembangan pembelajaran inovatif berbasis pendampingan bagi guru sekolah dasar. Abdimas Siliwangi, 1(1), 17. https://doi.org/10.22460/as.v1i1p17-25.36

Ratminingsih, N. M. (2016). Efektivitas media audio pembelajaran bahasa inggris berbasis lagu kreasi di kelas lima sekolah dasar. JPI (Jurnal Pendidikan Indonesia), 5(1), 27. https://doi.org/10.23887/jpi-undiksha.v5i1.8292

Retnawati, H. (2016). Hambatan guru matematika sekolah menengah pertama dalam menerapkan kurikulum baru. Jurnal Cakrawala Pendidikan, 3(3). https://doi.org/10.21831/cp.v3i3.7694

Santrock, J. W. (2011). Educational psychology. New York: McGraw-Hill.

Shanks, R. (2017). Mentoring beginning teachers: professional learning for mentees and mentors. International Journal of Mentoring and Coaching in Education, 6(3), 158-163. https://doi.org/10.1108/IJMCE-06-2017-0045

Sinsuw, A. A. E., \& Sambul, A. M. (2017). Pelatihan pengembangan media pembelajaran berbasis teknologi informasi bagi guru-guru SMP. Jurnal Teknik Elektro Dan Komputer, 6(3), 105-110. https://doi.org/10.35793/jtek.6.3.2017.18070

Suardana, I. N., \& Retug, N. (2017). Pelatihan pembuatan perangkat pembelajaran berbasis budaya Bali bagi guru-guru sains SMP di Kecamatan Buleleng. Jurnal Widya Laksana, 2(1), 9. https://doi.org/10.23887/jwl.v2i1.9125

Susanto, E., \& Retnawati, H. (2016). Perangkat pembelajaran matematika bercirikan PBL untuk mengembangkan HOTS siswa SMA. Jurnal Riset Pendidikan Matematika, 3(2), 189-197. 
Jurnal Prima Edukasia, 9 (1), 2021 - 64

Muhammad Sulthon, Pratiwi Pujiastuti, Heri Retnawati

https://doi.org/10.21831/jrpm.v3i2.10631

Syarifuddin, S. (2018). The effect of using the scientific approach through concept understanding and critical thinking in science. Jurnal Prima Edukasia, 6(1), 21-31. https://doi.org/10.21831/jpe.v6i1.15312

Zurqoni, Retnawati, H., Apino, E., \& Anazifa, R. D. (2018). Impact of character education implementation: A goal-free evaluation. Problems of Education in the 21st Century, 76(6), 881899. https://doi.org/10.33225/pec/18.76.881 